\title{
PERBEDAAN HASIL LATIHAN SENAM POCO-POCO OLAHRAGA MENGGUNAKAN METODE KONVENSIONAL DAN INSTRUKSIONAL SISWA LAKI-LAKI DAN PEREMPUAN DI SDN 75 KOTA BENGKULU
}

\author{
Oleh : \\ Hidayah Mustika Canggih \\ PENJAS FKIP UNIB, e-mail: hidayahmustika2107@gmail.com \\ Tono Sugihartono \\ Universitas Bengkulu \\ Defliyanto \\ Universitas Bengkulu
}

\begin{abstract}
Abstrak
Penelitian ini bertujuan untuk mengetahui Perbedaan hasil Latihan penguasaan Senam PocoPoco Olahraga Menggunakan Metode Konvensional dan Instruksional Siswa Laki-Laki Dan Perempuan Di SDN 75 Kota Bengkulu. Metode yang digunakan dalam penelitian ini adalah metode eksperimen. Sampel berjumlah 40 orang, dengan desain yang digunakan adalah two group Pre test-post test design. Instrumen penelitian ini untuk mengetahui Perbedaan Hasil Latihan Senam Poco-Poco Olahraga menggunakan metode konvensional dan instruksional siswa laki-laki dan perempuan. Teknik analisis data menggunakan uji ANOVA. Hasil peneliti ini diperoleh f-hitung 38.70 lebih besar dari f-tabel 2.86, artinya ada perbedaan yang signifikan dari Hasil Latihan Senam Poco-Poco Olahraga Menggunakan Metode Konvensional dan Instruksional Siswa Laki-Laki Dan Perempuan Di SDN 75 Kota Bengkulu. Artinya dari kedua kelompok metode konvensional dan intruksional, metode intruksional adalah metode yang lebih baik. Pada kelompok metode konvensional dan intruksional siswa perempuan lebih baik dari pada siswa laki-laki. Siswa laki-laki metode intruksional lebih baik dari pada siswa laki-laki metode konvensional.
\end{abstract}

Kata Kunci : Konvensional, Intruksional, Senam Poco-Poco Olahraga

\begin{abstract}
This study aims to determine the difference results of exercise Poco-Poco Gymnastics Using Conventional Methods and Instructional Students Boys And Girls In SDN 75 Bengkulu City. The method used in this research is the experimental method. The sample is 40 people, with the design used is two group Pre test-post test design. The instrument of this research is to know the difference of Poco-Poco Gymnastic Exercise Result using conventional and instructional method of boys and girls students. Data analysis technique used ANOVA test. The result of this research is obtained f-count 38.70 bigger than f-table 2.86, meaning there is significant difference from Poco-Poco Sport Gymnastic Exercise Using Conventional and Instructional Method of Boys and Girls Students at SDN 75 Kota Bengkulu. This means that from both groups of conventional and
\end{abstract}


intruksional methods, the intruksional method is the better method. In the group of conventional and instructional methods Girls students are better than Boys students. Students Boys methods are better than conventional Boys students.

Keywords: Conventional, Instructive, Poco-Poco Gymnastics Sports

\section{PENDAHULUAN}

Pendidikan berfungsi membentuk
watak serta peradaban bangsa yang
bermartabat dalam mencerdaskan kehidupan bangsa agar berkembangnya potensi peserta didik agar menjadi manusia yang beriman, bertaqwa kepada Tuhan Yang Maha Esa, berakhlak mulia, sehat, berilmu, cakap, kreatif, mandiri, dan menjadi warga negara yang berdemokrasi dan bertanggung jawab (UU SPN. No. 20).

Pendidikan jasmani merupakan bagian dari pendidikan secara umum. Pendidikan jasmani dapat di definisikan sebagai suatu proses pendidikan yang di tujukan untuk mencapai tujuan pendidikan melalui aktifitas fisik. Pendidkan Jasmani sebagai salah satu sub-sistem pendidikan yang berperan penting dalam mengembangakan kualiatas manusia Indonesia. Pendidikan jasmani memuat sejumlah materi, salah satunya adalah senam.

Materi senam irama atau senam ritmik dapat dikembangkan secara dinamik dan progresisive sesuai dengan tuntutan dan perkembangannya. Pengembangan senam ritmik yang dinamik menuntut upaya yang kreatif, sehingga dapat menarik minat pelakunya (termasuk siswa) dan memilih kegiatan tersebut untuk aktivitas olahraga.

Senam poco-poco merupakan senam yang sudah tidak asing bagi masyarakat di negara kita, kekayaan alam serta budaya yang ada di negara kita menjadikan negara kita kaya akan kreasi termasuk senam. Senam poco-poco merupakan salah satu contohnya. Senam poco-poco merupakan senam yang berasal dari Manado. Pada awalnya kata poco-poco merupakan salah satu seni tarian yang ada di Manado Sulawesi Utara. Namun kemudian lambat laun berubah menjadi sebuah senam yang diiringi dengan lagu khas Manado, irama yang rancak semakin membuat senam pocopoco ini banyak digemari masyarakat Indonesia. Boomingnya senam poco-poco pada awal tahun 2000an dimana hampir seluruh masyarakat Indonesia mengenal dan bisa melakukan senam ini. Kemudian pada tahun 2016 senam poco-poco di kembangkan menggunakan lagu-lagu olahraga dan gerakan yang didalamnya terdiri dari beberapa gerakan cabang olahraga contohnya atletik, bola kaki,tinju, renang, silat, angkat besi, voli, bulutangkis, dan basket.

Sekolah dasar merupakan pondasi Pendidikan di Indonesia, oleh karena itu tingkat hasil belajar atau latihan di luar sekolah perlu dipantau selalu, agar hasil belajar siswa di bidang pendidikan jasmani dapat memperoleh nilai yang memuaskan.

Dari hasil observasi terdapat informasi dari guru Penjas Sekolah Dasar Negeri 75 Kota bahwa dibandingkan dengan siswa perempuan siswa laki-laki cendrung susah menangkap pelajaran materi pembelajaran senam contohnya dalam melakukan gerakakan yang di ajarkan siswa sukar untuk mempraktekan kembali. Terdapat Informasi dari seorang guru mata pelajaran penjas di Sekolah Dasar Negeri 75 Kota Bengkulu memperlihatkan bahwa terkait dengan 
kemampuan aktivitas ritmik bahwa siswa laki-laki belum menujukan hasil yang baik di bandingkan dengan siswi perempuan dibidang non akademik terutama di bidang olahraga, kecepatan mencerna latihan yang diberikan pada siswa laki-laki dan perempuan yang berbeda, minat siswa/i untuk mengikuti latihan yang sangat kurang, metode instruksional belum di terapkan khususnya di bidang olahraga. Maka peneliti berinofasi memberikan bentuk metode latian konvensional dan instruksional.

Berdasarkan masalah di atas peneliti mencoba berinovasi mencari perbedaan hasil latihan siswa laki-laki dan perempuan dengan menerapkan metode latihan instruksional dan latihan konvensional senam poco-poco olahraga. Latihan konvensional atau latihan langsung, Suatu model pengajaran yang menuntut guru sebagai model yang menarik bagi siswa dalam mendemonstrasikan pengetahuan atau keterampilan yang akan dilatihkan kepada siswa secara langkah demi langkah.

Untuk menggunakan model pembelajaran langsung guru harus memiliki keterampilan mengenai apa yang akan diajarkan kepada siswa seperti keterampilan senam pocopoco olahraga. Berbeda dengan metode instruksional dengan memanfaatkan media audio visual, guru lebih mudah menyampaikan pembelajaran aktivitas ritmik kepada siswa khususnya di tingkat sekolah dasar. Media audio visual menyajikan gambar bergerak dikombinasikan dengan latar suara yang menjadi keunggulan media audio visual dengan media yang lain. Materi aktivitas ritmik membutuhkan latar suara sebagai pedoman ritme gerakan dan gambar bergerak sebagai pedoman rangkaian gerakan senam. Menggunakan media audio visual dalam pembelajaran aktivitas ritmik dapat memberikan kemudahan bagi guru dalam menyampaikan materi pembelajaran dengan ditampilkannya gambar bergerak dan suara yang dapat diputar ulang sehingga ketika siswa mengalami kebingungan dapat diputar ulang gerakannya.

Penerapan media audio visual juga dapat menarik minat siswa dalam pembelajaran aktivitas ritmik karena penggunanya belum pernah dilakukan sebelumnya. Selain itu guru dapat mengembangkan kemampuan kognitif, kreatif, dan inovatif yang lebih baik dengan harapan akan mendapatkan hasil pembelajaran yang lebih maksimal. Bentuk dari pemanfaatan teknologi informasi dalam media pembelajaran salah satunya dengan cara pengembangan media audio visual dalam penyampaian materi. Media audio visual atau multimedia memberikan kesempatan kepada guru untuk berlatih.

Atas dasar pertimbangan tersebut diatas, maka peneliti perlu mengadakan penelitian dengan judul "Perbedaan Hasil Latihan Senam Poco-Poco Olahraga Menggunakan Metode Konvensional dengan Instruksional Siswa Laki-Laki dan Perempuan di Sekolah Dasar Negeri 75 Kota Bengkulu".

Rumusan masalah yaitu:

Apakah ada perbedaan hasil latihan metode konvensioanl dan intruksional terhadap penguasaan senam poco-poco olahraga di Sekolah Dasar Negeri 75 Kota Bengkulu ? Apakah ada perbedaan hasil latihan metode konvensional dan intruksional pada siswa laki-laki terhadap penguasaan senam pocopoco olahraga di Sekolah Dasar Negeri 75 Kota Bengkulu?

Apakah ada perbedaan hasil latihan metode konfensional dan intruksional pada siswa perempuan terhadap penguasaan senam poco-poco olahraga di Sekolah Dasar Negeri 75 Kota Bengkulu? 


\section{METODE}

Desain Penelitian

Sesuai dengan judul penelitian, maka penelitian yang digunakan adalah penelitian eksperimen. Sugiyono (2007:64) Desain penelitian yang digunakan adalah "Two Group Pretest-Postes Design", yaitu desain penelitian yang terdapat Pretestsebelum diberikan perlakuan dan postes setelah diberi perlakuan. Dengan demikian dapat diketahui lebih akurat, karena dapat membandingkan dengan diadakan sebelum diberi perlakuan. Dengan latihan yang di berikan tersebut, dalam penelitian ini penulis ingin mengetahui apakah ada perbedaan hasil latihan dengan menggunakan metode konvensional dan instruksional pada siswa laki-laki dan perempuan. Ada pun desain penelitian sebagai berikut :

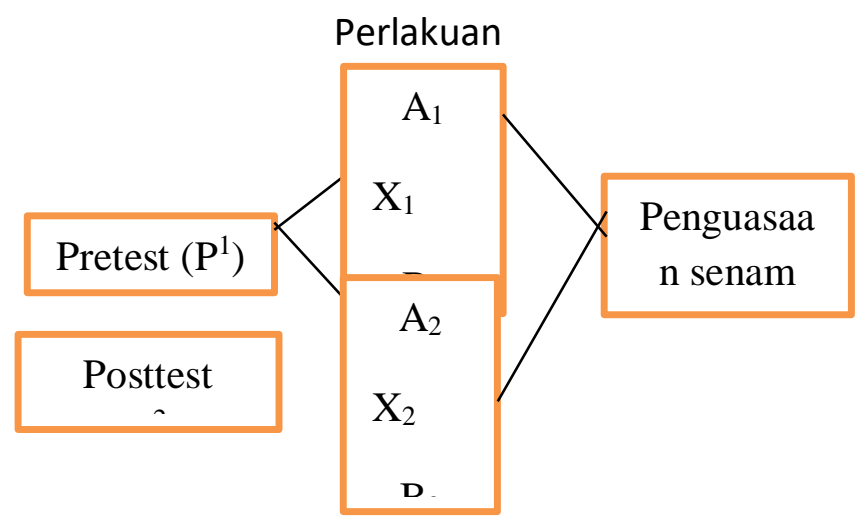

Gambar 2. Desain Two Group Pretest-Postes Design (sugiyono, 2007:32)

Keterangan :

$\mathrm{P}_{1}=$ Tes awal

$\mathrm{X}_{1}=$ latihan konvensional

$\mathrm{X}_{2}=$ latihan instruksional

$A_{1}=$ siswa laki- laki latihan konvensional

$\mathrm{B}_{1}=$ siswa perempuan lathan konvensional

$A_{2}=$ siswa laki-laki latihan instruksional

$\mathrm{B}_{2}=$ siswi perempuan latihan instruksional
$\mathrm{P}_{2}=$ Tes akhir

Tempat penelitian

Penelitian tentang eksperimen ini dilaksanakan di dalam dan di luar ruangan Sekolah Dasar Negeri Negeri 75 Kota Bengkulu.

Waktu penelitian

Penelitian ini akan dilaksanakan sejak dikeluarkannya surat penelitian. Selanjutnya di laksanakan selama 16 kali pertemuan, satu minggu diadakan 6 kali pertemuan, kelompok metode latihan instruksional dan konvensional masing- masing 3 kali pertemuan yang dilakuakan pada jam luar sekolah yaitu pada sore hari pukul 15:00 16:00.

Populasi

Populasi adalah keseluruhan subjek yang dimasukan untuk diselidiki (universal).Menurut Sugiyono, (2006: 89) mengatakan: Populasi adalah wilayah generalisasi yang terdiri atas objek atau subyek yang mempunyai kualitas dan karakteristik tertentu yang ditetapkan oleh peneliti untuk dipelajari dan kemudian di tarik kesimpulannya. Jadi yang dimaksud populasi adalah individu yang memiliki sifat yang sama walau presentase kesamaan itu sedikit, atau dengan kata lain pengertian tersebut mengandung maksud bahwa seluruh individu yang akan dijadikan sebagai obyek penelitian.Populasi penelitian ini adalah siswa/i kelas IV dan V A,B,C dan D dengan jumlah 281 SDN 75Kota Bengkulu.

Sampel

Sampel penelitian ini adalah siswa kelas IV dan V. Dari 281 siswa hanya di ambil $15 \%$ saja yaitu sebanyak 40 terdiri dari 20 siswa laki-laki dan 20 perempuan yang dipilih random atau secara acak. Sampel yang di 
ambil hanya 40 siswa karena mengingat penelitian ini adalah penelitian eksperimen ada beberapa pertimbangan seperti keterbatasan dana, waktu, dan tempat. Adapun rincian sampel siswa pada tabel di bawa ini :

Tabel 1. Sampel siswa kelas IV dan V Sekolah SDN 75 Kota Bengkulu.

\begin{tabular}{|l|l|l|l|}
\hline Jeniskelamin & \multicolumn{1}{|l|}{$\begin{array}{l}\text { Kelas } \\
\text { I V }\end{array}$} & Kelas V & Jumlah \\
\hline Laki-laki & 10 & 10 & 20 \\
\hline Perempuan & 10 & 10 & 20 \\
\hline Total & & & 40 \\
\hline
\end{tabular}

Variabel penelitian

Variabel adalah segala sesuatu yang berbentuk apa saja yang di tetapkan oleh peneliti untuk dipelajari sehingga diperoleh informasi oleh hal tersebut, kemudian di tarik kesimpulannya. Sugiyono (2006:42) dalam penelitian ini terdapat tiga variabel yaitu dua variabel bebas dan satu variabel terikat.

Variabel Bebas

Sugiyono (2012:39) Variabel bebas merupakan variabel yang mempengaruhi atau yang menjadi sebab perubahannya atau timbulnya variabel dependen (terikat). Pada penelitian ini yang menjadi variabel bebas adalah latihan dengan metode instruksional $\left(\mathrm{X}^{1}\right)$ dan latihan metode konvensional $\left(\mathrm{X}^{2}\right)$.

Variabel Terikat

Sugiyono (2012: 39) Variabel terikat merupakan variabel yang dipengaruhi atau yang menjadi akibat, karena adanya variabel bebas. Pada penelitian ini yang akan menjadi variabel terikat adalah tingkat penguasaan senam poco-poco olahraga pada siswa lakilaki dan perempuan .

Teknik Pengumpulan data
Sesuai dengan masalah dan hipotesis yang telah diajukan dalam judul penelitian ini, maka data yang akan dikumpulkan dalam penelitian ini siswa/i melakukan rangkaian gerakan menggunakan tes keterampilan Poco-poco Olahraga. Sebelum melakukan penelitian dilakukan langkah-langkah sebagai berikut :

\section{Dokumentasi}

Ridwan (2007:24) dokomentasi adalah ditunjuk untuk memperoleh data langsung ari tempat penelitian, meliputi buku-buku yang relevan, praturan-praturan, laporan kegiatan, film dokumenter, foto-foto dan data penelitian yang relevan.

Tes

Winarmi (2011:155) tes adalah seretetan atau latihan yang di gunakan untuk mengukur keterampilan, pengetahuan, sikap, intelejensi, kemampuan tau bakat yang dimiliki individu atau kelompok. Metode yang dilakukan pada penelitian ini adalah pretest dan postest.

Data yang akan dikumpulkan penelitian ini berupa daftar nama siswa yang dijadikan sebagai sampel penelitian yaitu siswa/siswi Sekolah Dasar Negeri 75 Kota Bengkulu.

1. Tes Awal (PreTest)

Tes awal (pretest) diberikan perlakuan berupa kegiatan penguasaan senam pocopoco olaharaga menggunakan metode latihan audiovisual instruksional dan latihan konvensional dilakukan. Tujuan dari pretest adalah untuk mengetahui kemampuan awal dari masing-masing siswa sebelum kegiatan pembelajaran berlangsung.

2. Tes Akhir (Post Test)
Setelah dilakukan pembelajaran
selama 16 kali pertemuan kemudian


diadakan tes akhir yang pelaksanaanya sama seperti awal.

\section{Instrumen penelitian}

Instrumen penelitian adalah suatu alat yang digunakan untuk mengukur fenomena alam maupun sosial yang di amati, secara spesifik semua fenomena ini disebut variabel penelitian Sugiyono (2006:114). Instrumen dalam penelitian ini adalah tes keterampilan poco-poco olahraga 2016. Instrumen kegiatan ini disusun oleh peniliti dan di bantu oleh ahli/pakar yang berpengalaman di bidang senam. Kemudian melakukan tes yaitu pretest (tes awal), pertemuan berikutnya diberikan program pembelajaran dan padaakhir pertemuan diadakan posttest (tes akhir).

Validitas dan Realibilitas instrumen

Suharsimi Arikunto dalam Novia Dessiyanti (2015:40) Validitas adalah suatu ukuran yang menunjukan tingkat-tingkat kevalidan atau kesasihan suatu instrumen. Suharsimi Arikunto dalam Novia Dessiyanti (2015:40) Realibilitas adalah suatu instrumen cukup dapat di percaya untuk digunakan sebagai alat pengumpulan data karena instrumen tersebut sudah baik. Instrumen dalam penelitian ini telah memenuhi ketentuan/syarat validitas isi (content validity). (lampiran 9 halaman 93)

Teknik Analisia Data

Sebelum menguji ada tidaknya perbedaan hasil latihan metode konvensional dan instruksional pada siswa laki laki dan perempuan Sekolah Dasar Negeri 75 Kota Bengkulu. Sugiyono (2011:38) teknik analisis data merupakan kegiatan setelah data dari seluruh responden atau sumber lain terkumpul. maka Uji $t$ harus memenuhi Uji syarat normalitas data syarathomogenitas varians jika memenuhi syarat tersebut maka selanjutnya dilakukan Uji syarat $t$ dan analisis varians (ANAVA).

1. Uji Syarat Normalitas

Uji normaliatas data dilakukan sebagai prasyarat untuk uji perbedaan, dari hasil uji persyaratan tersebut akan di ketahui apakah data berdestribusi normal atau sebaliknya. Sugiyono (2012:172)

\section{Uji Syarat Homogenitas Varians}

Uji homogenitas dilakukan untuk melihat apakah sample memiliki varian yang homogen atau tidak. Pengujian homogenitas digunakan rumus sebagai berikut:

$$
f=\frac{\text { variabel terbesar }}{\text { variabel terkecil }}
$$

Sugiyono (2012 : 199).

Membandingkan nilai $F_{\text {hitung }}$ dengan $F_{\text {tabel }}$ dengan rumus

dk pembilang: $n-1$ (untuk varian terbesar)

dk penyebut:n-1 (untuk varian terkecil)

Taraf signifikan $(0,05)$ maka dicari pada tabel $F$

Didapat dari tabel $\mathrm{F}$

Dengan kriteria pengujian

Jika : F Fitung $>F_{\text {tabel }}$ datahomogen dan jika $\mathrm{F}_{\text {hitung }}<\mathrm{F}_{\text {tabel }}$ berarti data tidak homogen.

3. Uji Statistik Perbedaan

Sudjana dalam Jimmy Ardiansah (2008:25)

\section{Analisis Varians (ANAVA) Satu Arah}

Supardi (2016:293) Analisis Varians Satu Arah adalah analisis varians yang digunakan untuk membandingkan antara tiga atau lebih variabel. Analisis varians satu arah dipergunakan dengan syarat data berdistribusi : independen, normal, dan homogen. 
Tabel 2.Tabel ANAVA Satu Arah

\begin{tabular}{|c|c|c|c|c|}
\hline $\begin{array}{l}\text { Sumber } \\
\text { Variasi }\end{array}$ & SS & $\begin{array}{l}D \\
f\end{array}$ & $\begin{array}{l}\text { Mean } \\
\text { Squar } \\
\text { e }\end{array}$ & Fraito \\
\hline $\begin{array}{l}\text { Between/g } \\
\text { rub }\end{array}$ & $\begin{array}{l}\text { SSB/SS } \\
\text { G }\end{array}$ & $\begin{array}{l}K \\
- \\
1\end{array}$ & $\begin{array}{l}M S B \\
=\frac{S S G}{k-1}\end{array}$ & $\begin{array}{l}F \\
=\frac{M S G}{M S W}\end{array}$ \\
\hline $\begin{array}{l}\text { Within/err } \\
\text { or }\end{array}$ & $\begin{array}{l}\text { SSW/S } \\
\text { SE }\end{array}$ & $\begin{array}{l}n \\
- \\
k\end{array}$ & $\begin{array}{l}M S W \\
=\frac{S S W}{N-1}\end{array}$ & \\
\hline Total & SST & $\begin{array}{l}- \\
1\end{array}$ & & \\
\hline
\end{tabular}

Supardi (2016:297)

Keterangan :

SSB/SSG = jumlah kuadrat diantara

SSW/SSE = jumlah kuadrat dalam

MSW =rata-rata variasi dalam kelompok

SST = jumah kuadrat total

$\mathrm{K}-1$ = derajat bebas kelas

$\mathrm{n}-\mathrm{k}=$ derajat bebas darai jumlah kuadrat

dalam

\section{HASIL DAN PEMBAHASAN}

Hasil

Penelitian ini dimaksudkan untuk mengetahui ada tidaknya perbedan hasil latihan penguasaan seam poco-poco olahraga menggunakan metode konvensional dan intruksional siswa laki-laki dan perempuan di SDN 75 Kota Bengkulu, Untuk mengetahuinya sebelum siswi diberikan perlakuan (treatment), siswi diberikan tes awal terlebih dahulu, setelah diberi tes awal barulah diberi perlakuan (treatment) yaitu latihan penguasaan senam poco-poco olahraga menggunakan metode konvensiona dan intruksional sebanyak 16 kali pertemuan, setelah diberi perlakuan maka siswa diberikan tes akhir. Adapun data nilai yang di dapat dari hasil pretest dan posttest :

\section{Deskripsi Hasil Uji Persyaratan}

Setelah selesai melakukan dan pengambilan data penelitian yang berjudul Perbedaan Hasil Latihan Senam Poco-Poco Olahraga Menggunakan Metode Konvensional dan Instruksional Siswa LakiLaki Dan Perempuan Di SDN 75 Kota Bengkulu, dengan melakukan pretest dan postest terhadap penguasaan senam pocopoco olahraga diperoleh data sebagai berikut:

2. Uji Normalitas

Uji normalitas bertujuan untuk mengetahui apakah data penelitian berdistribusi normal atau tidak. Kriteria pengujian yang digunakan adalah data berdistribusi normal jika nilai $T_{\text {hitung }}<T_{\text {tabel. }}$. Hasil pengujian normalitas pada data pre-tes dan post-tes penguasaan senm poco-poco sebagai berikut:

Tabel 6. Hasil Uji Normalitas Data

\begin{tabular}{|c|c|c|c|}
\hline \multicolumn{4}{|c|}{ Penelitian } \\
\hline $\begin{array}{c}\text { Data } \\
\text { Penelitian }\end{array}$ & $\begin{array}{c}T_{\text {hitun }} \\
\mathrm{g}\end{array}$ & $\mathrm{T}_{\text {tabel }}$ & $\begin{array}{c}\text { Kesimpula } \\
\mathrm{n}\end{array}$ \\
\hline $\begin{array}{c}\text { Pre-test } \\
\text { Konvension } \\
\text { al }\end{array}$ & 3.4 & $\begin{array}{c}9.44 \\
8\end{array}$ & Normal \\
\hline $\begin{array}{c}\text { Post-test } \\
\text { Konvension } \\
\text { al }\end{array}$ & 3.67 & $\begin{array}{c}9.44 \\
8\end{array}$ & Normal \\
\hline $\begin{array}{c}\text { Pre-test } \\
\text { intruksional }\end{array}$ & 4.27 & $\begin{array}{c}9.44 \\
8\end{array}$ & Normal \\
\hline $\begin{array}{c}\text { Post-test } \\
\text { inttruksiona } \\
\text { I }\end{array}$ & 5.17 & $\begin{array}{c}9,44 \\
8\end{array}$ & Normal \\
\hline
\end{tabular}

(Pengujian statistik pada halaman 5870 lampiran 4) 
Tabel di atas menunjukkan bahwa data penguasaan senam poco-poco olahraga siswa kelas 4 dan 5 SDN 75 Kota Bengkulu. Sebelum dan sesudah diberi perlakuan berdistribusi normal. Hal ini ditunjukkan dari hasil perhitungan yang menunjukan bahwa data penelitian memiliki nilai $T_{\text {hitung }}<T_{\text {tabel. }}$. Masing-masing data hasil penguasaan senam poco-poco olahraga adalah pre-test konvensional $\mathrm{T}_{\text {hitung }} 3.4<9,448 \mathrm{~T}_{\text {tabel, }}$ posttest konvensional $T_{\text {hitung }} 3.67<9,448 \mathrm{~T}_{\text {tabel, }}$ pretest intruksional $T_{\text {hitung }} 4,27<9,448 \mathrm{~T}_{\text {tabel, }}$ dan post-test intruksional $\mathrm{T}_{\text {hitung }} 5.17<$ 9,448 $\mathrm{T}_{\text {tabel. }}$

\section{Uji Homogenitas}

Uji homogen dilakuakan untuk mengetahui apakah semua data hasil penelitian merupakan data yang homogen atau tidak. Uji homogen dalam penelitian ini menggunakan Uji F. Kriteria pengujian yang digunakan dalam penelitian ini adalah data berdistribusi homogen jika $F_{\text {hitung }}<F_{\text {tabel. }}$. Hasil pengujian Uji $\mathrm{F}$ pada data penguasaan senm poco-poco sebagai berikut:

Tabel 7. Hasil Uji Homogenitas

\begin{tabular}{|c|c|c|l|}
\hline $\begin{array}{c}\text { Data } \\
\text { Penelitian }\end{array}$ & $F_{\text {hitung }}$ & $F_{\text {tabel }}$ & Kesimpulan \\
\hline Konvensional & 1.523 & 2.15 & Homogen \\
\hline Intruksional & 1.190 & 2.15 & Homogen \\
\hline
\end{tabular}

Tabel di atas menunjukan bahwa data penguasaan senam poco-poco olahraga siswa kelas 4 dan 5 SDN 75 Kota Bengkulu tersebut homogen.. Hal ini ditunjukan dari hasil perhitungan yang menunjukan bahwa data penelitian memiliki nilai hasil penguasaan senam poco-poco olahraga : varians konvensional F Fitung $1.523<F_{\text {tabel }}$ 2.15, dan varians intruksional $F_{\text {hitung }} 1.190<$ Ftabel 2.15 .

1. Uji Statistik Perbedaan

Uji perbedaan dilakukan untuk mengetahui apakah ada perbedaan hasil penelitian metode konvensional dan intruksional .

Tabel 8. Hasil Uji Perbedaan

(Pengujian statistik pada halaman 75-78 lampiran 6)

Dengan $\mathrm{dk}=\mathrm{n}-2=18$ di dapat $\mathrm{t}_{\text {tabel }}$ 2.101.Terlihat pada tabel di atas bahwa hasil penguasaan senam poco-poco olahraga antar pretest kedua kelompok tidak ada perbedaan karena t-hitung lebih kecil dari pada $t$-tabel ( $t_{\text {hitung }} 1,421<t_{\text {tabel }} 2.101$ ). Hasil penguasaan senam poco-poco olahraga pretest-postest menggunakan metode konvensional ternyata ada perbedan, karena diketahui t-hitung lebih besar dari pada ttabel (thitung $15.21>t_{\text {tabel }}$ 2.101). Hasil penguasaan senam poco-poco olahraga pretest-postest menggunakan metode intruksional ternyata ada perbedaan, hal ini diketahui hasil t-hitung lebih besar dari pada t-tabel (thitung $24.39>t_{\text {tabel }}$ 2.101). Hasil penguasaan senam poco-poco olahraga posttes kedua kelompok mempunyai perbedaan di ketahui hasil t-hitung lebih besar dari pada $t$-tabel ( $t_{\text {hitung }} 9.036>t_{\text {tabel }}$ 2.101). 
2. Uji ANAVA

Uji ANAVA digunakan untuk menguji perbedaan antar grub.

Tabel 9. Hasil Uji ANAVA

\begin{tabular}{|l|l|l|l|l|l|}
\hline $\begin{array}{l}\text { Sumb } \\
\text { er } \\
\text { Varias } \\
\text { i }\end{array}$ & $\begin{array}{l}\text { D } \\
\text { b }\end{array}$ & Jk & RJK & $\begin{array}{l}\text { Fitun } \\
\mathrm{g}\end{array}$ & $\begin{array}{l}F_{\text {tab }} \\
\text { el }\end{array}$ \\
\hline $\begin{array}{l}\text { Rata- } \\
\text { rata }\end{array}$ & 1 & 28900 & & & \\
\hline Antar & 3 & 7454 & $\begin{array}{l}2484 . \\
67\end{array}$ & $\begin{array}{l}38.7 \\
0\end{array}$ & $\begin{array}{l}2.8 \\
6\end{array}$ \\
\hline Dalam & $\begin{array}{l}3 \\
6\end{array}$ & $\begin{array}{l}2683.2 \\
3\end{array}$ & 74.53 & & \\
\hline Total & $\begin{array}{l}4 \\
0\end{array}$ & $\begin{array}{l}28974 \\
54\end{array}$ & & & \\
\hline
\end{tabular}

K-1=4-1= $3 \quad \frac{J K}{D b}=\frac{7454}{3}=2484.67$

$\frac{\operatorname{RJKA}(A)}{r j k(d)}=\frac{2484.67}{74.53}=38.70$ (F hitung $)$

$\mathrm{n}-4=40-4=36 \quad \frac{J K}{D b}=\frac{2683.23}{36}=74.53$

(Lihat Tabel F dengan 3/36) $\alpha=0.05$

Kriteria :

Dari tabel di atas terlihat $F_{\text {hitung }}$ $38.70>F_{\text {tabel }} 2.86$. Artinya dari semua kelompok terdapat perbedaan dari dari hasil penguasaan senam poco-poco olahraga metode konvensional dan intruksional siswa laki-laki dan perempuan di SDN 75 Kota Bengkulu.

\section{Pembahasan}

Penelitian ini bertujuan untuk melihat ada atau tidaknya perbedaan hasil latihan penguasaan senam poco-poco olahraga pada siswa laki-laki dan perempuan yang diberikan perlakuan metode konvensional dan metode insrtuksional. Penelitiaan ini menggunakan teknik random sampling atau

\begin{tabular}{|l|l|l|l|}
\hline \multicolumn{1}{|c|}{$\begin{array}{c}\text { Data } \\
\text { Penelitian }\end{array}$} & $T_{\text {hitung }}$ & $\mathrm{T}_{\text {tabel }}$ & Kesimpulan \\
\hline $\begin{array}{l}\text { Antar pretest } \\
\text { konvensional } \\
\text { dan } \\
\text { intruksional }\end{array}$ & 1.421 & 2.101 & $\begin{array}{l}\text { Tidak ada } \\
\text { perbedaan }\end{array}$ \\
\hline $\begin{array}{l}\text { Antar } \\
\text { posttest } \\
\text { konvensional } \\
\text { dan } \\
\text { Intruksional }\end{array}$ & 9.036 & 2.101 & $\begin{array}{l}\text { ada } \\
\text { perbedaan }\end{array}$ \\
\hline $\begin{array}{l}\text { Antar pretest } \\
\text { dan posttest } \\
\text { konvensional }\end{array}$ & 15.21 & 2.101 & $\begin{array}{l}\text { ada } \\
\text { perbedaan }\end{array}$ \\
\hline $\begin{array}{l}\text { Antar pretest } \\
\text { dan posttest } \\
\text { intruksional }\end{array}$ & 24.39 & 2.101 & $\begin{array}{l}\text { ada } \\
\text { perbedaan }\end{array}$ \\
\hline
\end{tabular}

pengambilan sampel penelitian secara acak. Maka dari itu dari seluruh jumlah siswa kelas IV dan V yang ada di SDN 75 Kota Bengkulu hanya diambil beberapa saja sesuai ketentuan jumlah penelitian. Sampel yang sudah dipilih inilah yang nantinya akan dijadikan sebagai sampel penelitian untuk melihat adakah perbedaan hasil latihan penguasaan senam poco-poco pada siswa laki-laki dan perempuan yang diberikan perlakuan metode konvensional dan metode insrtuksional.

Desain penelitian yang digunakan dalam penelitian ini adalah two group pretest-posttest design dengan kata lain penelitian ini di dalamnya ada dua grub penelitian yang akan di ambil datanya masing-masing dua kali yaitu dilakukan tes awal (sebelum diberikan perlakuan) dan tes akhir (sesudah diberi perlakuan). Instrumen penelitian ini menggunakan rubrik penilaian yang sudah di sahkan oleh ahli/pakar yang bersangkutan atau berpengalaman terhadap senam poco-poco olahraga. Instrumen dalam penelitian ini telah memenuhi 
ketentuan/syarat validitas isi (content validity). (lampiran 7)

Pada penelitian ini dapat di lihat bahwa tes akhir (post-test) yang di lakukan menunjukan bahwa nilai penguasaan senam poco-poco olahraga pada metode konvensional memiliki nilai tertinggi 93 dan nilai rata-rata yang di peroleh 66.65, sedangkan pada metode intruksional menunjukan memiliki nilai tertinggi 99 dan memiliki niali rata-rata yaitu 88 berdasarkan hasil penelitian yang telah di lakukan di lihat dari hasil nilai penguasaan senam poco-poco olahraga menggunakan metode konvensional dan intruksional.

Dari perbedaan hasil penguasaan senam akibat bentuk metode latihan yang diberikan, terlihat bahwa metode intruksional poco-poco olahraga lebih baik dibandingkan dengan metode konvensional. sesuai dengan penelitian yang dilakukan oleh Aleha Minarti (2011) bahwa dengan latihan intruksional audiovisual sangat baik untuk diterapkan dalam pembelajaran senam.

Karena pada metode intruksional pocopoco olahraga peserta didik dapat melihat, mendengar, mengamati, meniru secara lansung gerakan yang ada pada video pocopoco olahraga. Kemudian berdasarkan penelitian oleh Juris Suriani (2013) bahwa pelaksanaan menggunakan intruksional yang dilakukan oleh guru dalam proses belajar mengajar sangat baik.

Perhitungan dengan t-test untuk mengetahui perbedaan masing-masing kelompok. Bahwa hasil penguasaan senam poco-poco olahraga antar pretest kedua kelompok tidak ada perbedaan karena $\mathrm{t}$ hitung lebih kecil dari pada t-tabel (thitung $1,421<t_{\text {tabel }} 2.101$ ). Hasil penguasaan senam poco-poco olahraga pretest-postest menggunakan metode konvensional ternyata ada perbedan, karena diketahui thitung lebih besar dari pada $t$-tabel ( $t_{\text {hitung }}$ $15.21>t_{\text {tabel }}$ 2.101). Hasil penguasaan senam poco-poco olahraga pretest-postest menggunakan metode intruksional ternyata ada perbedaan, hal ini diketahui hasil thitung lebih besar dari pada t-tabel (thitung $24.39>t_{\text {tabel }}$ 2.101). Hasil penguasaan senam poco-poco olahraga posttes kedua kelompok mempunyai perbedaan di ketahui hasil t-hitung lebih besar dari pada t-tabel (thitung $9.036>t_{\text {tabel }} 2.101$ ).

Perhitungan dengan ANAVA untuk mengetahui ada perbedaan antar grup hal ini terlihat dari f-hitung lebih besar dari pada f-tabel ( $F_{\text {hitung }} 38.70>F_{\text {tabel }}$ 2.86). Berdasarkan hasil pengujian yang telah di lakukan sebelumnya menyatakan bahwa ada perbedaan hasil latihan penguasaan senam poco-poco metode konvensional dan metode intruksional pada siswa laki-laki dan perempuan.

yaitu:

1. Dari hasil penguasaan senam pocopoco olahraga kelompok metode konvensional dan intruksional, ternyata ada perbedaan yaitu di lihat dari hasil rata-rata tes akhir kelompok konvensional sebeser 80,5 dan nilai rata-rata tes akhir kelompok intruksional sebesar 88 .

2. Dari hasil penguasaan senam pocopoco olahraga siswa laki-laki dan perempuan kelompok konvensional, ternyata ada perbedaan di lihat dari hasil rata-rata tes akhir siswa lakilaki kelompok konvensional sebesar 78.6 dan nilai rata-rata tes akhir siswa perempuan kelompok konvensional sebesar 84.7.

3. Dari hasil penguasaan senam pocopoco olahraga siswa laki-laki dan perempuan kelompok intruksional, 
ternyata ada perbedaan di lihat dari hasil rata-rata tes akhir siswa lakilaki kelompok intruksional sebesar 86 dan nilai rata-rata tes akhir siswa perempuan kelompok intruksional sebesar 90.7 .

4. Dari hasil penguasaan senam pocopoco olahraga siswa laki-laki kelompok konvensional dan intruksional, ternyata ada perbedaan di lihat dari hasil ratarata tes akhir siswa laki-laki kelompok intruksional sebesar 78.6 dan nilai rata-rata tes akhir siswa laki-laki kelompok intruksional sebesar 86.

5. Dari hasil penguasaan senam pocopoco olahraga siswa perempuan kelompok konvensional dan intruksional, ternyata ada perbedaan di lihat dari hasil ratarata tes akhir siswa perempuan kelompok konvensional sebeser 84.7 dan nilai rata-rata tes akhir siswa perempuan kelompok intruksional sebesar 90.7.

\section{Simpulan}

Berdasarkan hasil penelitian diatas selain memiliki perbedaan antara kelompok metode konvensional dan metode intruksional siswa laki-laki dan perempuan, dapat disimpulkan latihan menggunakan metode konvensional dan metode intruksional sama-sama dapat meningkatkan kemampuan dalam penguasaan senam poco-poco olahraga, akan tetapi metode intruksional lebih baik di bandingkan dengan metode konvensional. Dari data yang sudah diperoleh yaitu hasil metode konvensional di dapat pretest sebesar 66.65 dan hasil posttest sebesar 80.5 dengan presentase peningkatan $13.85 \%$. sedangkan metode intruksional di dapat pretest sebesar 68 dan hasil posttest sebesar 88 dengan presentase peningkatan 20\%. Hasil penelitian menunjukan bahwa selisih rata-rata (mean) antara pretest dan posttest siswa setelah mengikuti program latihan metode konvensional dan metode intruksioanl sebanyak 16 kali pertemuan dapat menunjukan peningkatan terhadap kemamampuan penguasaan senam pocopoco olahraga.

Berdasarkan hasil pengujian ANAVA bahwa $F_{\text {hitung }} 38.70>F_{\text {tabel }} 2.86$. Artinya terdapat perbedaan yang signifikan dari hasil latihan senam poco-poco olahraga menggunakan metode konvensional dan intruksional pada siswa laki-laki dan perempuan di SDN 75 Kota Bengkulu, dengan demikian hasil pengujian terbukti bahwa hipotesis yang diajukan sesuai dengan hasil peneliti, yaitu :

1. Dari hasil penguasaan senam poco-poco olahraga kelompok metode konvensional dan intruksional, ternyata ada perbedaan yaitu di lihat dari hasil rata-rata tes akhir kelompok konvensional sebeser 80,5 dan nilai rata-rata tes akhir kelompok intruksional sebesar 88.

2. Dari hasil penguasaan senam poco-poco olahraga siswa laki-laki kelompok konvensional da intruksioal, ternyata ada perbedaan di lihat dari hasil rata-rata tes akhir siswa laki-laki kelompok intruksional sebeser 78.6 dan nilai rata-rata tes akhir siswa laki-laki kelompok intruksional sebesar 86.

3. Dari hasil penguasaan senam poco-poco olahraga siswa perempuan kelompok konvensional dan intruksional, ternyata ada perbedaan di lihat dari hasil rata-rata tes akhir siswa perempuan kelompok konvensional sebeser 84.7 dan nilai ratarata tes akhir siswa perempuan kelompok intruksional sebesar 90.7. 


\section{Saran}

Dari kesimpulan penelitian diatas, ada beberapa saran yang dapat disampaikan yaitu :

1. Bagi anak yang mempunyai kendala atas penguasaan senam poco-poco olahraga yang masih kurang hendaknya dapat meningkatkan dengan latihan secara rutin salah satunya dengan metode intruksional.

2. Seorang guru diharapkan mampu menerapkan metode latihan yang efektif dengan merancang bentuk latihan yang baik agar diperoleh hasil latihan yang optimal, salah satunya dengan metode latihan intruksional.

3. Bagi peneliti yang ingin melanjutkan penelitian ini agar dapat menjadikan penelitian ini sebagai bahan informasi dan penelitian dengan populasi atau sampel yang berbeda dan dalam jumlah yang lebih banyak lagi.

\section{DAFTAR PUSTAKA}

Atmaja.P. (2014). Psikologi Anak. : Rajagrapindo Persada.

Aqib.Z, Ali M. (2016). Kumpulan Metode pembelajaran. Bandung : CV.Yrama widya.

Ardiansyah.J. (2008). Perbandingan Metode Latihan Konvensional dengan Metode Sistem Individu Terhadap Peningkatan Kemampuan Lompat Jauh di SDN 46 air bening Bermani Ulu. Bengkulu. Universitas Bengkulu.

Arsyad.A. (2014). Media pembelajaran. Jakarta: Rajagrapindo Persada.

Bozi.N. (2010). Perbedaan Hasil Latihan Passing Bawah antara Metode
Lansung dan tidak Lansung dalam Permainan Bola Voli Siswa Kelas V SD Negeri $130 \quad$ Seluma. Bengkulu. Universitas Bengkulu.

Dini Rosdiani. (2013). Dinamika olahraga dan pengembangan nilai. Bandung: Alfabeta.

Haryono.A, Arief SS, Rahardjo. (2014). Media pendidikan. Jakarta : Rajagrapindo Persada.

Insanistyo.B. (2014). Manajemen pendidikan jasmani dan olahraga.Bengkulu: Unit Penerbitan FKIP Universitas Bengkulu.

Kemenpora. (2016). Senam Poco-poco Olahraga. FOKBI.

Mahmud. H. (2017). Pendidikan Karakter. Bandung : Alfabeta.

Pujianto.D, Bayu I. (2013). Dasar-dasar penelitian pendidikan Jasmani. Bengkulu: Universitas Bengkulu.

Rusman. (2014). Model-model pemeblajaran. Jakarta : PT Rajagrafindo Persada.

Sugiyono. (2016). Metode penelitian kuantitatif,kualitatif, dan $R \& D$. Bandung: Alfabeta.

Sori. E. (2014). Penerapam model pembelajaran langsung dengan media video untuk meningkatkan kemampuan lempar turbo siswa kelas V SDN 04 Lebong atas. Bengkulu : Universitas Bengkulu

Supardi. (2017). Statistik Penelitian Pendidikan : PT PT Rajagrafindo Persada. 
Syahara. S. (2008). Dasar-dasar Senam.

Jakarta : Univerisas Terbuka.

Wiarto. G. (2015). Inovasi pembelajaran dalam pendidikan jasmani. Yogyakarta : Laksitas.

Tangkudung, James. (2012). Kepelatihan Olahraga Pembinaan Prestasi Olahraga. Jakarta: Cerdas jaya ,(2016).Macam-macam

Metodologi Penelitian. Jakarta: Lensa Media Pustaka Indonesia

,(2018). Sport Psychometrics Dasar-dasar dan instrument Psikometri. Depok :Rajagrafindo persada 